\title{
The Revolution Turns Eighty:
}

\section{New Literature on the Russian}

\section{Revolution and its Aftermath}

\author{
ANATOL SHMELEV
}

Orlando Figes, A People's Tragedy: The Russian Revolution, 1891-1924 (London: Jonathan Cape, I996 (reviewed in Pimlico edition, I997), 923 pp., ISBN oI $50-24364-X$.

Vladimir N. Brovkin, Behind the Front Lines of the Russian Civil War: Political Parties and Social Movements in Russia, I918-1922 (Princeton, NJ: Princeton University Press, I994), 455 pp., ISBN o-69I-03278-5.

Edward Acton, William G. Rosenberg and Vladimir Iu. Cherniaev, eds., Critical Companion to the Russian Revolution 1914-1921 (Bloomington and Indianapolis: Indiana University Press, I997), 782 pp., ISBN o-340-6I 454-4.

Ronald Kowalski, The Russian Revolution, 1917-1921 (London and New York: Routledge, I997), 269 pp., ISBN o-4I 5-I2437-9.

André Liebich. From the Other Shore: Russian Social Democracy after 1921 (Cambridge, MA, and London: Harvard University Press, I997), 476 pp., ISBN o674-325I7-6.

Over eighty years after it occurred, the Russian Revolution continues to engender debate among professional historians as well as the interested public. If the French Revolution is any guide, this interest is very likely to continue indefinitely. Causes and consequences, the meaning and significance of individual component events, the interplay of social forces, and cultural, political, intellectual, economic and a myriad of other aspects have and will continue to be examined and sifted through. Last year - the eightieth anniversary - produced a number of important works on the revolution and its consequences. Those under review here, including an older one from I994, represent a range of approaches, from introductory accounts for the general reader to summations of the state of knowledge to histories of the revolution's 'losers'.

Written in a clear, engaging and elegant manner, Orlando Figes's A People's Traged $y$ weighs in as a solid explanation of the deep-rooted causes of the revolution, its development and results. To be sure, the significance of this work lies more in the author's desire to make the revolution accessible to the general reader than in presenting new interpretations or evidence. Even so, the book touches on issues of historiographical debate and offers generous quotes from unpublished memoirs and

Contemporary European History, 8, I (I999), pp. I27-I39 (C) I999 Cambridge University Press

Printed in the United Kingdom 
other archival sources. The sweeping canvas Figes spreads before the reader and the monumental events he depicts, together with narrative devices such as bringing in the fates of a handful of representative actors in this historical drama give the work the feeling of a grand novel, reminiscent, at least in the period described, of Doctor Zhivago.

Figes begins his story with the great famine of I89I. This was a watershed event in the development of Russia in that it showed just how clear the fissure dividing government from society had become. He paints a picture in starkly contrasting tones of the lives and outlooks of the various social elements that made up Russia from the high bureaucracy through liberal, reform-minded landed nobles down to land-starved peasants and oppressed national and religious minorities. He emphasises the feudal nature of the old regime and views the actions of Nicholas II as aimed at returning Russia to a seventeenth-century ideal of his own construction. It is no accident that the tome begins with a description of the tercentenary celebration of the Romanov ruling dynasty. In some respects, indeed, the seventeenth-century was not so far away - the conditions of life of the peasants in their villages were quite primitive. But this was really an illusion, for the advance of technology and new political and social ideas were putting an increasing strain on the fabric that held state and society together.

The condition of the peasantry, where social and economic stratification was increasingly turning the flank of customary values and traditions, was especially volatile. Although in the beginning this hazard was more potential than actual - as the early failures of the populists to rouse the peasantry indicated - the growing pressure brought on by the wars of the beginning of the century, the revolution of I905 and the Stolypin reforms clearly showed that the problems of the village were demanding a more far-reaching solution than the government was prepared to offer. As a response to land-hunger and underproductivity, some advanced peasants and landed nobility attempted to introduce modern methods of production, but the main remedy (such as it was) for rural problems was provided by the burgeoning industrial development of the urban centres. Of course, the draw-off of peasants to the cities created problems of its own, which Figes describes in the context of the growing mood of rebellion and defiance across class boundaries that characterised Nicholas's reign from its outset. An increasingly radical intelligentsia led the estrangement of society; group after group found cooperation with the government either impossible or undesirable until, finally, no supporters were left.

In this manner, over one-third of the text is devoted to the background to I9I7, setting the stage for the author's account of why the revolution took the path that it did. Yet the picture of pre-revolutionary Russia that Figes draws is neither comprehensive nor objective, nor can it be: if the author's purpose is to explain the causes of the revolution, it is necessary to emphasise certain factors - the weakness of the state and its inability to govern effectively, the tensions within society, the problems of urbanisation and modernisation.

Certainly the state of affairs in Russia was very complex, and not every event, fact or issue can be given an equal position in a causal chain, especially one linked at 
times by distorted connections. Thus pages are spent discussing Rasputin's sexual organs and adventures, querying whether Prince Iusupov may not have been his lover and deciding that the Empress was 'too narrow-minded' (p. 93) to have been. The claim that the Russian army 'was at least the equal of the German army' in men and matériel in I9I4 (p. 253) is questionable. Figes's desire to pin every mistake made in the First World War on the 'inflexible', 'authoritarian' and 'inefficient' government of Nicholas II gets caught up in its own contradictions - Nicholas is said to have favoured 'Aristocratic but incompetent cavalrymen' (p. 259), yet his chief of staff is the thoroughly professional General M. V. Alekseev. Were the 'endless blunders' (p. 260) of the aristocratic generals (including a case of ordering fire on friendly troops) really very different from the blunders of democratic generals on the western front or in the Second World War or Vietnam? And how is one to reconcile the concepts of 'Muscovite tsardom' (p. 6) and the 'German-dominated Romanov court' (p. 248) with which Figes characterises Nicholas's reign? The use of the term 'peasants', making little distinction between those in the central provinces and those, for instance, in Siberia, is too general, while 'permanent apartheid' to describe the government's policies toward the national minorities (p. 70 ) is certainly too severe, for many non-Russians achieved high posts in the civil service and the military.

The theme of violence, which plays a prominent role in this book, also calls for a comparative approach. Was the life of a Russian peasant at the turn of the century really that different from, for example, a French peasant (as described, for example, by Emile Guillaumin in his Life of a Simple Man)? Was it even qualitatively so far removed from the violence and brutishness endemic in today's ghettoes? Nor is the Russian culture the only one to have created proverbs reflecting violence: 'A woman, a dog, a waltnut tree, the more you beat them, the better they be' is a perhaps rarely used today - English equivalent to Figes's examples from the Russian.

In this manner the unique causative moments of the Russian Revolution are set adrift in a sea of anecdote and detail that, even if relevant, only serves to show that a violent revolution can happen anywhere. Moreover, the too-glib tone and 'pop history' approach prevalent to some extent in the first section of the book tend to upstage precisely the tragic aspects of this people's tragedy.

It is in describing the complexity of events and moods of I9I7 that Figes's mastery emerges. The essence of his approach and the key to the title of the work lie in an event depicted on pp. 43 I-432: during the July I9I7 upheaval in Petrograd, a worker, 'fuming with anger and frustration' at having been put in his place by Chkheidze, the chairman of the Petrograd Soviet, found himself unable to vent his emotions. 'Centuries of serfdom and subservience had not prepared him to stand up to his political masters - and in that lay the tragedy of the Russian people as a whole,' concludes the author (p. 432). This vignette calls to mind a similar one on p. 223, when Prime Minister Stolypin disarmed a suspicious-looking peasant agitator by asking him to hand over his (Stolypin's) coat. Stolypin, Figes comments, 'had managed to assert his mastery - the mastery of a squire - over his peasant adversary'.

What both these illustrations underscore is the basic premise of this work, which 
can perhaps be described as cultural determinism. It was 'centuries of serfdom and subservience', the violent and brutish nature of life in Russia that caused the revolution to take the path it did. While this is not untrue, deterministic arguments do generally tend to oversimplify events to make them fit into prefabricated forms.

Thus everything that happened in Russia before I9I7 seems to have paved the way for revolution. Even in educating peasants, 'the old regime had sown the seeds of its own destruction' (p. 60o). And the course of the revolution and civil war also seems to have been predetermined, which leads in some cases to a distortion of fact. Thus, 'As soon as his [General N. N. Iudenich's] army entered Soviet soil ... its mainly Russian conscripts began to desert' (p. 67I) - in fact, the opposite was true. In general, the author's knowledge of and interest in the counterrevolution is weak and therefore serious explanation of its failure is replaced by meaningless anecdote and derision - Kolchak was never a mining engineer (p. 586) and Kornilov's democratic credentials (lowly origins and the arrest of the imperial family) were certainly no worse than Brusilov's (general of the imperial suite). Were Kornilov's eyes more 'mousy' than Lenin's, and what could this have to do with the success of one and failure of the other? Vrangel did not constantly intrigue against Denikin (p. 660), and the portrayal of the Whites as being motivated solely by hatred and revenge (p. 556) is hardly accurate or fair. This does not mean that Figes is any more tolerant of the Bolsheviks - he sees the banning of the Kadet party shortly after the Bolsheviks took power as 'the declaration of war on a whole social class' (p. 509). Indeed, Lenin himself is blamed for inciting the civil war (p. 6I6). Bolshevik methods in the countryside and the rise of a new Bolshevik elite, with its privileges and corruption, are described by the author without apology. On the whole, except for the lapses noted above, the author presents a clear and convincing picture of events and their significance.

The rich language, skilful narrative and scope of the book are certain to make it popular among general readers, and, indeed, it has already been the recipient of a number of awards. However, Figes's central argument that 'The Russian people were trapped by the tyranny of their own history' (p. 808) tends to lead to an oversimplified, deterministic presentation. There is no sense that the author is asking any questions of his material or encouraging the reader to ask questions; there is every sense that he is taking the reader by the hand and leading him or her through the period with one ready answer in hand for every question: 'such was the tyranny of Russian history ...'

Vladimir Brovkin's Behind the Front Lines of the Russian Civil War, on the other hand, asks its questions forcefully. Brovkin is dissatisfied with the revisionist view of the civil war and argues that 'The idea that it is possible to win a civil war against the will of the majority of the population has not been seriously considered' (p. 6). He sees the civil war as far more complex than the mere struggle between Reds and Whites - in fact, he consciously de-emphasises this struggle in order to shed greater light on the story of worker and peasant protest, of shifting identities and allegiances and of complicated political and social interaction. Like Figes, Brovkin sees the Russian people not as victims of events, but as participants (is it impossible to be 
both?); he also sees in the emerging Bolshevik leadership what Figes called 'a mirror-image of the Tsarist state' (p. 8I 3 ). But it is apparent from his approach that Brovkin intends to dot every ' $i$ ' and cross every ' $t$ ' - he refers to tyrannical Bolshevik 'little tsars' who bear more than a passing resemblance to some of the sympathetic heroes in Figes's account.

In contrast to Figes's not irredeemable Bolsheviks, Brovkin's represent the essence of moral and material corruption, cynicism and power hunger. If, for example, Lenin held to a conciliatory policy toward the Mensheviks early on, it was due not to a love for democracy, but to kowtowing before foreign socialist opinion (p. 26). The civil war was not a question of events forcing Lenin into a more autocratic and rigid mode so much as allowing him to throw off his mask and reveal his true nature. Ultimately, the Bolsheviks forced themselves into the role of dictators; thereafter, 'Bolshevik rule had to remain a dictatorship or disappear' (p. 89).

Brovkin notes that the years I9I8-I9 represented an unending chain of workers' strikes against the Bolshevik government, to which the latter reacted as if workers were its enemies. The fact that soldiers and sailors often either supported the strikers or refused to participate in suppression forced the government to rely more and more on brutal methods against the population at large - lockouts, the taking of hostages, executions, confiscation of ration cards, and so on. To be sure, the author notes, the extinction of the opposition press makes it difficult to ascertain the extent of actual popular opposition to the Bolsheviks. While this begs the question of the value of the opposition press as an accurate and objective source, it does seem fair to conclude with the author that workers' resentment at Communist parvenus and the growing severity of the system was leading to a change in attitude. Allegiance to the government had been conditional on being able to identify with it as a workers' and peasants' government; when this identification faltered, allegiance also began to dissipate.

The centrality of economic or political reasons for popular disaffection with the Bolsheviks has been debated by Brovkin and others elsewhere (Slavic Review, vol. 44, no. 2, summer 1985), and here Brovkin returns to his thesis with renewed vigour - political considerations could, and often did, lead to anti-Bolshevik strikes and discontent independently of economic difficulties. The results were varied. In some cases Red troops deserted to the Whites, in other cases Bolshevik policies eased the way for White military successes (as with the Cossacks). In yet other instances, worker sympathies were on the side of the Whites in places as far removed from any front as Tver (p. I68). 'There were no Whites in central Russia, but there was a civil war' (p. I62), concludes the author in discussing another type of anti-Bolshevism - the peasant Green movement. For those to whom the Whites represented a politically unacceptable or geographically unavailable alternative to Bolshevism, the Green movement was the path of choice. Yet who were the Greens? Brovkin's definition (p. I45) is wide: some were deserters from the Red Army who wanted merely to be left alone, others were active peasant rebels. Their politics were unclear, their allegiances mercurial; one group elected its own tsar; 
others served Reds and Whites and deserted time and again. The one thing they had in common was a desire to protect their personal and local interests against whatever authority tried to infringe on them.

Confusion reigns, however, on the Greens' organisation and effectiveness. On pp. I49-50 they are described as largely well-organised; by p. I6I they are 'poorly organized'. In between we see that in the majority of cases they offered only weak or non-existent resistance to the smallest Cheka detachments sent against them. To be sure, there are well-known examples of large-scale rebellion, but to describe the Greens as a 'volunteer popular army' (p. I6I) is to imbue them with a cohesion, discipline, homogeneity, organisation and command structure which they simply did not have (and this explains their ultimate defeat). Indeed, this reader was struck more by the elemental, emotional and uncoordinated nature of peasant rebellion.

Resistance to the Bolsheviks leads Brovkin to ask why - after all the rebellions and policy failures - the Bolsheviks did not pursue different tactics. The answer he finds is that 'Lenin preferred ... to rely on force' (p. I87). This resulted in the strengthening of the bureaucracy, the war machine and instruments of terror. At the same time, White policies in the territories held by them were also causing great discontent. Caught between two unpleasant possibilities, workers and peasants tended toward the socially closer Reds. This is not to say that there was no 'third force' (in the parlance of the day) in Russia. But this force - anti-Red and antiWhite - proved incapable of connecting with the workers and the Greens to form a unified movement. Brovkin finds the Mensheviks and Socialist Revolutionaries (SR) lacking in both unity and political insight: both parties were split into factions and neither could offer both a viable alternative programme and the means to effect it. Yet at the same time, if Brovkin can define the 'partly successful' (p. I84) SR course only in terms of ultimate failure, then how is the reader to make sense of its meaning and significance?

The primacy the author gives to politics is apparent in the emphasis he places on parties. Indeed, he seems almost to be building a 'party model' of the civil war. Whenever a class or group opts for a programme or makes any kind of political decision, it is labelled as being influenced by SRs or affiliated with Menshevism, and so on. Thus the Kuban Cossacks in autumn I9I9 with their 'federative plans for Russia, and especially their ardent defence of the Constituent Assembly, are unmistakably in accord with the SR political platform' (p. 225). Yet Denikin had also promised to convene the Constituent Assembly (albeit a newly elected one), and federalism on the Kuban is too complex an issue to be reduced to an SR platform - its roots also lie in the Ukrainian heritage of half the Cossacks, and in the Kadet Cossack politician M. A. Karaulov's I9I7 idea of a South-East Union. Perhaps the rigidity of this party approach also explains the lack of a discussion of Vrangel's land and labour policies - they are neither reactionary nor Kadet nor an SR-Menshevik mutation. Another difficult case is that of the workers of Izhevsk and Votkinsk, whose loyalty to the socialist Committee of the Constituent Assembly was fully transferred to Admiral Kolchak. What really emerges from the evidence is a picture of the underdevelopment of parties, of leaders who were in every sense 
underwhelming, of factional splits over issues major and minor and of an inability to put the national interest above the party interest.

Brovkin's approach allows us to see clearly some of the shortcomings of previous work, and it is here that he carves out his historiographical niche. He excels at analysing the Bolshevik atomisation of society, the exertion of control, the creation and destruction of 'wreckers, enemies and spies' (p. 268, emphasis in original). These terms, so reminiscent of a later era, are no accident, for Brovkin has set himself the task of exploding the " "good Lenin, bad Stalin" myth' (p. 269). What follows is a litany of the ills the Bolsheviks had brought on Russia by I 920 - militarised labour, intolerable conditions of life for workers and peasants, a rigged electoral system and physical repression (again with terminology common in the I93os: in the eyes of the Cheka, a strike at a Tula factory in 1920 is 'engineered by Polish spies and Black Hundreds in order to weaken the might of the Red Army' (p. 293)). But if it was relatively easy to deal with worker unrest, the peasantry represented a more formidable opponent. Bolshevik methods - merciless requisitioning, robbery, provocation, vicious reprisals - led to huge uprisings around Tambov, Saratov, Tobolsk. Similar circumstances led to discontent in Petrograd and an uprising in Kronstadt; Brovkin does an excellent job of showing just how symptomatic these events were of 'a general crisis of the Communist order' (p. 397).

Thus the author concludes that it is possible to win a civil war against the will of the population. By I92 I the Bolsheviks were ruling Russia like 'a conquered country in medieval times' (p. 309), while the situation in the countryside was one of 'low-intensity warfare' (p. 316). This unhappy state was the result of antidemocratic policies vigorously pursued and enforced by means of terror and repression.

If Brovkin's text represents a fundamentally healthy questioning of some implicit and explicit revisionist assumptions, then the Critical Companion to the Russian Revolution represents, in some degree, a number of summaries of revisionist arguments in various areas of research. Despite the introduction of one of its editors, warning scholars of the twin dangers inherent in any rejection of revisionist argument - Pipesianism and post-modern neo-Pipesianism, the Critical Companion is much more than a partisan work: it offers the reader a variety of views on an entire complex of issues related to the revolution, civil war, and the entire I9I 4-2 I period. A stellar international line-up of scholars presents the fruits of recent research, stimulates debate and sets the agenda for the future. William Rosenberg's perceptive introductory essay places the varied contributions to the volume in an overarching framework, which draws the reader into the current discourse in the field. Statebuilding, locations of power, economic processes, ideology, social identity, the meanings of October and the complexities of the civil war are all condensed into those essential components and interrelations that make for an easy grasp of the problems involved. This immediately sets the tone for the solid and stimulating essays that follow.

The title of this work is very appropriate, for the essays that comprise it really make excellent companion pieces both to general studies as well as to the 
monographs that have and will come out with more detailed analyses. They offer a critical perspective, historiographical background, lists of suggested reading and an interpretive framework certain to be of use to a reader of any background.

The first section of the book describes some of the key events of the I9I4-2I period. Dominic Lieven sees the First World War as winnable for Russia, whose army was more effective than generally thought. Tsuyoshi Hasegawa, covering the February revolution, propounds the view of a colleague that the Tsarist regime was successful 'in creating a system of wartime mobilisation which was resilient enough to withstand three years of war' (p. 49), yet himself refers to the 'profound malaise of the dying regime' (p. 58) in February.

Apparent in all the essays is the crucial, central role of the First World War in determining events. Whether it was through the economic strains it caused, the activities of the Petrograd garrison or soldiers' committees, the moral and political consequences of the failed June offensive or General Kornilov's uprising, the war pervaded every aspect of the revolution, and the desire for peace was one of its strongest motive forces. Another major thread running through I9I7 was how the radicalisation of the masses effectively torpedoed any chance of forming a coalition government - first between liberals and socialists and later among socialists alone; only Lenin was able to ride this wave effectively into power. Both Alexander Rabinowitch and Evan Mawdsley (quoting the Russian historian E. G. Gimpel'son) tend to see the Bolsheviks' securing of power outside a coalition as making civil war inevitable. Also in this section, David Foglesong offers a model piece on the role and significance of intervention in the civil war.

The second section of the volume deals with personalities, covering the major leaders of the revolutionary period. Michael Melancon on Victor Chernov and Alexander Rabinowitch on Maria Spridonova shed light on the Socialist Revolutionaries and their split. The fiery Chernov emerges as a careful politician in I9I7, albeit lacking 'a sense of political timing' (p. I36). Spiridonova represents a key piece of the I9I7-I 8 puzzle - the left SRs. Boris Kolonitskii's Kerensky, using the SR's name more than actively affiliating himself with that party, sought consensus (at least at first) with the forces on his right. Kolonitskii rightly avoids giving us the hysterical Kerensky of the popular imagination (insisting that he attuned his behaviour to the mood of the moment and the audience) and offers instead a brilliant analysis of the 'Kerensky cult' in I9I7. The weakest treatment is reserved for the White generals, where an overly schematic text is laden with factual error Admiral Kolchak's age is off by a number of years; divisions are 'expanded' into brigades; foreign, rather than domestic, pressure is seen as influencing Vrangel's leftlooking policies.

The fourth section, on parties, contains few surprises, but the fifth and sixth, on institutions, social groups, identities and cultures offer excellent summaries of the areas where most of the research has been concentrated over the past twenty years. Those readers particularly interested in developing areas of research would do well to read Aleksei Markov's piece on education, Elizabeth Waters and Barbara Clements on women, family and gender, Kolonitskii on the press, M. V. 
Shkarovskii on the Russian Orthodox Church, Figes on the peasantry (several essays) and Richard Stites on ritual and symbols. This is not by any means to say that the other essays are unimportant - all have a great deal to offer the reader and together they exude a stimulating sense of vitality and interaction. Notably absent, however, is any sense of popular religion, whether it be Orthodoxy or any of the other numerous faiths of the former empire. Indeed, aside from a chapter on the Jews in Part VIII (more in terms of a nationality issue) and Shkarovskii's piece on the official church, there is only passing mention of religion in a few of the works in this volume (notably in Stites's and Waters's contributions, mainly in the context of tradition). Was religion really such a non-issue in I9I7? Certainly this is one area which scholarship has largely left untouched. Another theme absent from the pages of this work is that of crime and legality, though changing perceptions of criminality and justice (even as extensions of morality) are central to this period. Peter Gatrell's chapter on the refugees of the First World War opens up a fresh topic and leads one to reflect on another relatively unstudied theme - the fate of Russian POWs abroad and foreign POWs in Russia. Other areas offering enormous research potential are addressed by Dominic Lieven (the aristocracy and upper classes), Robert C. Williams (the emigration) and Shane O'Rourke (the Cossacks). However, the welltilled soil of traditionally popular areas also contains a number of questions that demand clarification.

The seventh section, on economic issues and everyday life concentrates more on the former. William Rosenberg uses statistics to support a grim picture of the disruption and chaos that forced people out of their usual modes of life. Lars Lih and Silvana Malle, discussing the grain monopoly and War Communism respectively, point out that in many cases the Soviet government simply took over institutions and policies that were in place before them, but with the addition of new ideological and practical twists. Malle in particular emphasises Bolshevik coercive policies and ideological paradigms over civil war exigencies in the formation of War Communism.

The collapse of the Soviet Union and the appearance of a multitude of individual states on its former territory and in eastern Europe have contributed to a renewed scholarly interest in national minorities. This is reflected in the last section of the Critical Companion, where most of the outlying regions of the former Russian empire are covered. Significantly absent are those that did not achieve independence or were far from the periphery - Tatars, Bashkirs, Buryats, Kalmyks and others (again indicating the wealth of opportunity for future study).

Ronald Suny leads into the section with a discussion of the conflicting interests of state (empire) and nation, which the Provisional Government proved unable to solve. The remaining essays discuss this contradiction in detail in the various regions. Some followed a path through calls for autonomy and self-rule to hopes of federation and finally to independence; for others the path led back to republic status in the Soviet empire. Several of the authors, particularly Mark von Hagen on the Ukraine and Martha Brill Olcott on central Asia, note the difficulties of national self-definition that the collapse of the empire thrust on its minorities. The essays in 
this section underscore the profound importance of a topic that merits greater consideration both in light of these new countries' search for their own pasts as well as approaches and methodologies emphasising discourse and identity.

Thus the Critical Companion is in both form and content an extremely welcome addition to the field. Undergraduates in particular should be directed to this resource both for its accessible and focused introductions as well as for the literature, ideas and directions of study to which it points the student.

Another text which is directed primarily toward college-level courses is Ronald Kowalski's The Russian Revolution, 1917-1921. The compiler/author of this work was faced with an impossible task - expressing the depth and breadth of the entire I9I7-2 I period in fewer than 300 pages. This title is part of the Routledge 'Sources in History' series and thus reflects the peculiarities of the series' approach. The goal is not so much to present readers with complete translations of significant documents (as is the typical goal of a 'reader', with which this book shares an external similarity), but rather to 'provide texts which will allow students to achieve facility in "thinking historically"' (p. ix). Thus, despite the compiler's best intentions, the resulting selections sometimes degenerate into a collection of sound bites. Some egregious examples: the Constituent Assembly's 'Declaration of the Rights of the Working and Exploited People' (pp. I04-5) and the Constitution of the RSFSR (pp. I09-Io), both hideously pockmarked by countless ellipses.

As a result, one hesitates to think of this book as a supplementary primary source text for a history course. Although its purpose as defined in the series introduction is to teach students the basic skills of historical analysis (by bringing out questions of who wrote and why, when and for whom the documents were written), the central rule that historical documents must be seen in their entirety is neglected. The editors have opened themselves up to the same critical examination they are encouraging in the prospective student - what was edited out and why, and was this justified? Moreover, the fact that some of the documents are published in English for the first time is of little significance if they have been savagely abridged.

If, however, one puts aside the intentions of the series and reads the work as a regular textbook with some very long and numerous quotes, it works quite well. This is not a history of the revolution; rather, it mixes historical documents with historiographical analysis to show how historians interpret documents and how they reach the conclusions that they do. In this the book undoubtedly serves an important purpose. Kowalski's introductory essay is a brief but lucid excursion into the relatively recent (I960s-90s) historiography of the revolution, including both Soviet/Russian and Western approaches. Thereafter, between documents and chapters he ably helps the reader navigate among revisionists and traditionalists, schools of thought stressing social, political and economic factors, actors and historians. The result is something of a critical companion to the Critical Companion.

Of course, while it is impossible to reflect the entire spectrum of historiography in one work, there are notable lacunae. George Katkov's work is discussed in relation to the February revolution, only to be summarily dismissed, yet he is not even mentioned in the discussion of the Kornilov affair. Later, the author insists 
(like Brovkin) that 'mass elemental rebellions against the Bolsheviks did not erupt until the final defeat of the Whites secured the peasants against the possible return of the landlords' (p. I47), but Figes's view (not controverting the significance of the White defeat) that they resulted from the Bolsheviks 'taking the last stocks of seed' (Critical Companion, p. 55I) seems a more pertinent explanation. To say that the Right SRs 'under Avksentiev, continued to be more hostile to the Bolsheviks than the Whites' (p. 227) is to ignore their propaganda activity in the west in I9I9-20, which certainly did more harm to the Whites than to the Bolsheviks.

Thus, all things considered, this text will be useful to those wishing to get a clear exposition of the historical debates over the events that comprise the revolution and the civil war. At the same time, unlike the Critical Companion, the text cannot stand alone as an introduction and can only be useful as supplemental reading.

Entirely different from all the above works in tone and content is the final object of review. What receives a throwaway line from Brovkin, that the right and centreleft Mensheviks 'continued their acrimonious debates' (p. 267) for over 40 years after the end of the civil war, becomes the subject of André Liebich's masterful study, From the Other Shore: Russian Social Democracy after 1921. At first glance, such a work might seem inconsequential: why study the Mensheviks after they had spun from the centre of political turmoil beyond its outer fringes? But Liebich's brilliant, well-reasoned and elegant introduction on the raison d'être of 'exile history' immediately grasps the reader's attention, focusing it on a topic that becomes in the author's hands not a fringe of history, but something central to human and historical concerns.

Nor does the author consider the Mensheviks' role as a political force to be finished by the early I920s. He notes that even outside Russia they had 'a certain type of power or influence by virtue of [their] ... ability to define the terms of debate, to set agenda ... to provide information to decision makers, to obstruct policies, or even to obtain a veto power over certain options' (p. 5). Liebich sees in the Menshevik exiles something of a precursor to 'Eurocommunists', considers their importance in the establishment of Kremlinology and examines their influence on the historiography of the revolution and the USSR. Suddenly the Mensheviks in exile are not so unimportant.

The tone of the study is that of a 'collective biography', and indeed the first two chapters of the book, on the development of Menshevism up to I92 I, seem almost like a family portrait. Perhaps this is a reflection of the fact that some of the leading Mensheviks were related to one another (most often through marriage). Referring to his protagonists as 'our Mensheviks', the author makes his sympathies clear, but this is also a device for narrowing the focus to exclude the extra-party right Mensheviks. Though the author does devote some passages to the latter, particularly in terms of Boris Nicolaevsky acting as a go-between, more attention to them would have given the study greater relief and perspective, particularly since many of them were well-known in their own right.

What did it mean to be an exiled Menshevik? Liebich examines the different experiences of a cross-section of party adherents. For some it primarily meant being 
exiles - these were Russia-focused. For others it primarily meant being socialdemocrats - these were internationally focused. Liebich chronicles the successes of the latter in adjusting to their new lives and roles. Unlike the mass of the Russian emigrants - with which they consciously avoided confusing themselves - many Mensheviks became successful businessmen, influential journalists (writing for and editing foreign periodicals), and even prominent politicians and opinion makers. In part this was due to their founding and work in the Labour and Socialist International, but even where not directly connected with that organisation, they had a profound impact.

Liebich considers their party organ, Sotsialisticheskii Vestnik, to be well-informed, although his comparison of it with the New York Times's reporting on Russia (p. I42) (especially of Walter Duranty vintage) is not much of a compliment. Their early reporting on Soviet events, though not without miscalculations, made the Mensheviks 'authoritative spokesmen for Russia and ... prime interpreters of Russian events within the international socialist movement' (p. I 52). Indeed, after the Second World War, their influence extended far beyond the international socialist movement.

In this manner the Mensheviks substituted a muted, but still quite effective, indirect influence on direct political action. The author notes that most of the terminology later applied to the Soviet Union was present in Menshevik literature in the I920s. He discusses their role in popularising the use of terms such as 'Bonapartism' and 'totalitarianism', the personal contacts with the French Socialist Prime Minister Léon Blum, and even how Sotsialisticheskii Vestnik came to express mainstream Cold War opinion in its 'irritation at insufficient appreciation of the Soviet threat' (p. 287) after the Second World War.

It is curious at the very least to consider how the Mensheviks, invoking terms like 'totalitarianism' and writing about labour camps and such, came to represent what is now considered a reactionary, Cold War-driven view of the Soviet Union, while at the same time remaining committed to socialist ideals. Congregating in America after the Second World War, they actively assimilated into American academic and political life, some, indeed, considering themselves 'more American than Russian' (p. 299). Together with a new generation (their offspring), they found support in the American labour movement, the Rand School and other organisations, and continued to exert political and theoretical influence through books and journals (particularly the New Leader).

This is a remarkable tale written to a high order of scholarship. Liebich exposes an untouched mass of sources, raises important new issues (many of them central to our understanding of the Cold War and twentieth-century international labour and socialist movements) and ultimately defines a new subject for study.

Each of the books examined here has its own niche to fill. Figes lays out the territory for the general reader. The Critical Companion goes deeper, giving those with a special interest an opportunity to see where historians have been and where they are going; it engages the issues of the nature and parameters of debate over the revolution. Kowalski's text is useful as supplementary reading for a college course. 
Brovkin's work is a massed attack on received revisionist wisdom, shedding much needed light on a neglected area. Liebich's is, in this reader's opinion, the most original and fascinating study in this group, even though it is not exactly central to our knowledge of the revolution as an event. What all these works have in common is an ability to show how rich the period is and how much work remains to be done. One expects that the hundred-year anniversary will bring in a crop of studies that will similarly offer new vistas for future research along with a critical examination of past historiographical experience. 